Authors' contribution/

Wkład autorów:

A. Zaplanowanie badań/

Study design

B. Zebranie danych/

Data collection

C. Analiza statystyczna/

Statistical analysis

D. Interpretacja danych/

Data interpretation

E. Przygotowanie tekstu/

Manuscript preparation

F. Opracowanie

piśmiennictwa/

Literature search

G. Pozyskanie funduszy/

Funds collection

\section{INFLUENCE OF SELECTED AGRICULTURAL POLICY INSTRUMENTS ON THE REGIONAL VARIATION IN CHANGES IN MILK PRODUCTION IN POLAND}

\section{WPŁYW WYBRANYCH INSTRUMENTÓW POLITYKI ROLNEJ NA REGIONALNE ZRÓŻNICOWANIE ZMIAN W PRODUKCJI MLEKA W POLSCE}

\author{
Andrzej Parzonko ${ }^{1(\mathrm{~A}, \mathrm{~B}, \mathrm{C}, \mathrm{D}, \mathrm{E}, \mathrm{F}, \mathrm{G})}$
}

${ }^{1}$ Warsaw University of Life Sciences SGGW, Faculty of Economic Sciences Szkoła Główna Gospodarstwa Wiejskiego w Warszawie, Wydział Nauk Ekonomicznych

Parzonko A. (2018), Influence of selected agricultural policy instruments on the regional variation in changes in milk production in Poland/ Wpływ wybranych instrumentów polityki rolnej na regionalne zróżnicowanie zmian $w$ produkcji mleka w Polsce. Economic and Regional Studies, Vol. 11, No. 1, pp. 76-89. https://doi.org/10.29316/ers-seir.2018.06

\section{ORIGINAL ARTICLE}

JEL code: Q18

Submitted:

August 2017

Accepted:

March 2018

Tables: 2

Figures: 2

References: 23

\section{Summary}

Subject and purpose of work: The objectives of the elaboration are the following: 1) to analyze the regional changes (at the level of poviats) in the number of farms involved in milk production over the period 2002-2010;2) to present the main factors affecting the ongoing changes in Polish farms oriented at milk production; 3) to determine the impact of the measure 121. "Modernization of agricultural holdings" under the RDP 2007-2013 and the applied system of direct subsidies for the development of farms oriented at milk production. Materials and methods: The work has been prepared on the basis of the analysis and synthesis of the source literature, statistical data collected and the author's own reflections. Results: In Poland, in the years 2002-2010 there was a distinct regional differentiation in the pace of the ongoing changes in the dairy sector. The regions, where we observe the development of milk production, include almost the entire Podlaskie Province, the northern part of the Mazowieckie Province and the south-eastern part of the Warmińsko-Mazurskie Province. Conclusions: Within the RDP 2007-2013, significant funds were allocated to support the modernization of agricultural farms. Mainly under the measure 121 "Modernization of agricultural holdings" the investments were carried out in relation to the purchase of mobile equipment, they represented $89 \%$ of all investments. This was partly due to the actual demand and administrative procedures that stimulated these types of investments.

Keywords: dairy farms, regions, structural funds, direct subsidies

\section{Streszczenie}

Przedmiot i cele pracy: Cele opracowania sprowadzają się do: 1) analizy zmian regionalnych (na poziomie powiatów) w liczbie gospodarstw zajmujących się produkcją mleka w latach 20022010; 2) przedstawienia głównych czynników oddziałujących na dokonujące się zmiany w polskich gospodarstwach ukierunkowanych na produkcję mleka; 3) określenia wpływu działania 121. „Modernizacja gospodarstw rolnych" w ramach PROW 2007-2013 oraz stosowanego sytemu dopłat bezpośrednich na rozwój gospodarstw ukierunkowanych na produkcję mleka. Materiały i metody: Praca została wykonana na podstawie analizy i syntezy literatury przedmiotu, zebranych danych statystycznych oraz własnych przemyśleń autora. Wyniki: W Polsce występowało w latach 20022010 wyraźne zróżnicowanie regionalne w tempie dokonujących się zmian w sektorze mleczarskim. Do regionu rozwijającego produkcję mleka można zaliczyć prawie całe województwo podlaskie, północną część województwa mazowieckiego oraz południowo-wschodnią część województwa warmińsko-mazurskiego. Wnioski: W ramach PROW 2007-2013 przeznaczono znaczne środki na dofinansowanie modernizacji gospodarstw rolniczych. Głównie w ramach działania 121. „Modernizacja gospodarstw rolnych" realizowano inwestycje związane z zakupem sprzętu ruchomego, które stanowiły 89\% wszystkich inwestycji. Wynikało to po części z faktycznego zapotrzebowania oraz procedur administracyjnych, które stymulowały tego typu inwestycje.

Słowa kluczowe: gospodarstwa mleczne, regiony, fundusze strukturalne, dopłaty bezpośrednie

\footnotetext{
Address for correspondence/ Adres korespondencyjny: dr hab. inż. Andrzej Parzonko (ORCID 0000-0002-8130-0376), Szkoła Główna Gospodarstwa Wiejskiego w Warszawie, Wydział Nauk Ekonomicznych, Katedra Ekonomiki i Organizacji Przedsiębiorstw, ul. Nowoursynowska 166, 02-787 Warszawa, Polska; tel. +4822 593-42 -21; e-mail: andrzej_parzonko@sggw.pl

Journal indexed in/ Czasopismo indeksowane w: AgEcon Search, AGRO, BazEkon, Index Copernicus Journal Master List, ICV 2016: 92,91; Polish Ministry of Science and Higher Education 2016: 9 points / AgEcon Search, AGRO, BazEkon, Index Copernicus Journal Master List ICV 2016: 92.91; Ministerstwie Nauki i Szkolnictwa Wyższego 2016: 9 punktów. Copyright: (c) 2018 Pope John Paul II State School of Higher Education in Biała Podlaska, Andrzej Parzonko. All articles are distributed under the terms of the Creative Commons Attribution-NonCommercial-ShareAlike 4.0 International (CC BY-NC-SA 4.0) License (http://creativecommons.org/licenses/by-nc-sa/4.0/), allowing third parties to copy and redistribute the material in any medium or format and to remix, transform, and build upon the material, provided the original work is properly cited and states its license.
} 


\section{Introduction}

Poland has relatively good natural conditions for cattle breeding and production of milk. The country is dominated by lowlands and therefore cultivation of fodder plants used in cattle breeding does not encounter significant limitations (Falkowski 2001). The country lies in an area of moderate climate, which is considered to be the most favourable for dairy cattle breeding. Certain natural limitations to dairy cattle breeding include insignificant resources of water and relatively low precipitation, which influences yielding of fodder plants (mainly of grasslands and corn). Among other things, it is thanks to favourable natural conditions for milk production in Poland that it occupies (in particular years) 11th-13th place in the world (Statistical Yearbook of Agriculture 2016) in terms of milk production. In the years 2004-2015, the overall milk production in our country successively demonstrated a growing trend, despite the operating production quota system. The growth in production, accompanied by unfortunately still low consumption of milk and dairy products, resulted in increased export. The volume of dairy products turnovers in 2003 amounted to EUR $278.4 \mathrm{mln}$, whereas in 2009 it was already EUR $836.2 \mathrm{mln}$. It should be noted, however, that positive trends in foreign trade in dairy products in the years 2015-2016 slowed down and Polish farms, despite their continuous development, lost their advantageous position against the entities from the leading EU countries (The dairy market, the state and prospects 2004-2016). A wide range of economic factors had a significant influence on changes in milk production and processing in Poland (SeremakBulge 2005, Dzun 2012, Parzonko 2013). A noticeable problem is the polarisation of regions in terms of cattle breeding and milk production. Especially after 2004, a deeper specialisation of agricultural farms is observed in Poland as well as concentration of specific kinds of agricultural production in particular regions. This phenomenon (to a certain extent) is not really in line with the concept of sustainable agricultural development (particularly in terms of environment). Deeper specialization of agricultural farms in milk production results in changes in the structure of sowing. In case of units with limited land resources, the crops are limited to corn silage and grassland (Parzonko 2002). Corn must often be grown as monoculture.

\section{Objectives and methodology of the research}

The objectives of the elaboration are the following: 1) to analyze the regional changes (at the level of poviats) in the number of farms involved in milk production over the period 2002-2010;2) to present the main factors affecting the ongoing changes in Polish farms oriented at milk production; $3)$ to determine the impact of the measure 121 . "Modernization of agricultural holdings" under the RDP 2007-2013 and the applied system of direct subsidies on the development of farms oriented at milk production.

\section{Wstęp}

Polska charakteryzuje się stosunkowo dobrymi warunkami przyrodniczymi do chowu bydła i produkcji mleka. Przewaga terenów nizinnych powoduje, że uprawa roślin pastewnych wykorzystywanych w chowie bydła nie napotyka zasadniczych ograniczeń (Falkowski 2001). Położenie w klimacie umiarkowanym uważane jest za najbardziej korzystne dla chowu bydła mlecznego. Pewnym ograniczeniem przyrodniczym są małe zasoby wody i stosunkowo niskie opady atmosferyczne, wpływające na poziom plonowania roślin pastewnych (głównie użytków zielonych i kukurydzy). Między innymi, korzystne uwarunkowania przyrodnicze do produkcji mleka w Polsce sprawiają, że pod względem wielkości produkcji mleka zajmujemy (w zależności od roku) 11-13 miejsce na świecie (Rocznik Statystyczny Rolnictwa 2016). W latach 2004 - 2015 sukcesywnie globalna produkcja mleka wykazywała tendencję rosnącą, mimo funkcjonującego systemu kwotowania produkcji. Efektem wzrostu produkcji, niestety przy ciągle niskim spożyciu mleka i przetworów mlecznych, był wzrost eksportu. Saldo obrotów produktami mlecznymi w 2003 roku wynosiło 278,4 mln euro, natomiast w 2015 roku było to już $850 \mathrm{mln}$ euro. Zaznaczyć jednak należy, że pozytywne tendencje $\mathrm{w}$ handlu zagranicznym produktami mlecznymi w latach 2015-2016 wyhamowały a polskie gospodarstwa rolnicze, mimo ciągłego rozwoju tracą swoje przewagi na tle podmiotów z wiodących krajów UE (Rynek mleka, stan i perspektywy 2004-2016). Szeroka grupa czynników ekonomicznych miała zasadniczy wpływ na zmiany w produkcji i przetwórstwie mleka w Polsce (Seremak-Bulge 2005, Dzun 2012, Parzonko 2013). Problemem, który daje się zauważyć, jest polaryzacja regionów w chowie krów i produkcji mleka. Szczególnie po 2004 roku można zauważyć głębszą specjalizację gospodarstw rolniczych oraz koncentrację określonej produkcji rolniczej $\mathrm{w}$ danym regionie. Zjawisko to stoi (w pewnym zakresie) w opozycji z koncepcją zrównoważonego rozwoju rolnictwa (szczególnie w aspekcie środowiskowym). Głębsza specjalizacja gospodarstw w kierunku produkcji mleka pociąga zmiany w strukturze zasiewów. $\mathrm{W}$ jednostkach, dysponujących małymi zasobami ziemi, uprawy ogranicza się do kukurydzy na kiszonkę i użytków zielonych (Parzonko 2002). Często kukurydza musi być uprawiana w monokulturze.

\section{Cele i metodyka badań}

Cele opracowania sprowadzają się do: 1) analizy zmian regionalnych (na poziomie powiatów) w liczbie gospodarstw zajmujących się produkcją mleka w latach 2002-2010, 2) przedstawienia głównych czynników oddziałujących na dokonujące się zmiany w polskich gospodarstwach ukierunkowanych na produkcję mleka, 3) określenia wpływu działania 121. „Modernizacja gospodarstw rolnych” w ramach PROW 2007-2013 oraz stosowanego sytemu dopłat bezpośrednich na rozwój gospodarstw ukierunkowanych na produkcję mleka. 
A relative point efficiency indicator (Manteuffel 1979) was used for the purpose of overall assessment of the concentration of dairy cows breeding in particular poviats (the density of cows and its change in the years 2002-2010). This method consists in allocating a certain number of points to selected indicators or meters (in this case the density of cows and quantitative changes in the density in the years 2002-2010). Scoring consists in the fact that the unit (in this case a poviat) achieving the best value of a given indicator or meter receives 100 points, while the unit in which the given indicator or meter has the worst value - 0 points. The remaining ones receive the points, which are calculated according to the following formula:

$$
L=\frac{a \times 100}{d}
$$

$\mathrm{L}$ - the number of points

$\mathrm{a}$ - the difference between the value of a given indicator achieved by a given unit (poviat) and the worst value

$\mathrm{d}$ - the difference between the best value and the worst value of the indicator in the surveyed population

To separate regions where we can observe the development or reduction of milk production, the data from the General Agricultural Census (the last one was carried out in 2010, hence the final date of the conducted analysis) was implemented. In order to identify the main factors that determine the ongoing changes in Polish farms oriented at milk production, the research with the use of a questionnaire was carried out in 85 municipalities within the region defined as the one which develops milk production.

Published and unpublished data of ARMA were used to assess the mechanisms supporting the development of dairy farms.

\section{Regional differentiation of milk production in Poland}

An economic region is an area of a certain economic specialization resulting from the use of endo - and exogenous development factors. This approach has been extended by R. Domański (2002) and K. Kuciński (2009). The basic factors in the development are the resources of a particular territory, i.e. the local population (social capital), environment, capital (on this basis a classification of factors of development has been prepared, e.g. in spatial development). Economic and agricultural literature presents the division into agricultural regions. Stola $W$. and Szczęsny R. (2004) distinguished 10 agricultural regions of the first order, which differ in the layout of natural and internal features of agriculture (types of farms and implemented types of production). W. Michna (2001) suggests a division of Poland into three Macroregions: 1) Macroregion I, which includes rural areas with the dominance of very small agricultural farms and the expectations of the rural population for non-agricultural employment. 2) Macroregion II, which includes rural areas dominated by multi-
Do łącznej oceny koncentracji chowu krów mlecznych w poszczególnych powiatach (obsady krów oraz jej zmian w latach 2002-2010) posłużono się wskaźnikiem względnej efektywności punktowej (Manteuffel 1979). Metoda ta polega na przydzielaniu określonej liczby punktów wybranym wskaźnikom lub miernikom (w tym przypadku odsada krów oraz ilościowe zmiany obsady w latach 2002-2010). Punktowanie polega na tym, że jednostka (w tym przypadku powiat) osiagająca najlepszą wartość danego wskaźnika lub miernika otrzymuje 100 punktów, natomiast jednostka, w którym dany wskaźnik lub miernik ma wartość najgorszą - 0 punktów. Pozostałe otrzymują liczby punktów, które oblicza się według podanej formuły:

$$
L=\frac{a \times 100}{d}
$$

\section{L - Liczba punktów}

a - różnica między wartością danego wskaźnika w danej jednostce (powiecie) a wartością najgorszą

d - różnica między wartością najlepszą a najgorszą warto-

ścią wskaźnika w badanej zbiorowości

Do wydzielenia regionów rozwijających i ograniczających produkcję mleka przyjęto dane z Powszechnego Spisu Rolnego (ostatni przeprowadzony był w 2010 roku stąd data końcowa prowadzonej analizy). W celu wskazania głównych czynników oddziałujących na dokonujące się zmiany w polskich gospodarstwach ukierunkowanych na produkcję mleka przeprowadzono badania z zastosowaniem kwestionariusza ankiety w 85 gminach z regionu zdefiniowanego jako rozwijający produkcję mleka.

Do oceny stosowanych mechanizmów wspierających rozwój gospodarstw mlecznych wykorzystano publikowane i niepublikowane dane z ARiMR.

\section{Regionalne zróżnicowanie produkcji mleka w Polsce}

Region ekonomiczny to obszar o określonej specjalizacji gospodarczej, będącej wynikiem wykorzystania endo - i egzogenicznych czynników rozwoju. Rozwinięcie tego ujęcia proponują R. Domański (2002) i K. Kuciński (2009). Za podstawowe czynniki rozwoju uważa się zasoby określonego terytorium, tzn. miejscową ludność (kapitał społeczny), środowisko, kapitał (na tej podstawie sporządzono klasyfikację czynników rozwoju np. w gospodarce przestrzennej). W literaturze ekonomiczno-rolniczej są próby wydzielania regionów rolniczych. Stola W. i Szczęsny R. (2004) wyróżnili 10 regionów rolniczych pierwszego rzędu, które różnią się układem cech przyrodniczych i wewnętrznych rolnictwa (typy gospodarstw rolniczych i realizowane kierunki produkcji). W. Michna (2001) proponuje podzielić Polskę na trzy makroregiony: 1) Makroregion I, w którym znajdują się obszary wiejskie o dominacji bardzo małych gospodarstw rolnych oraz oczekiwań ludności wiejskiej na pozarolnicze zatrudnienie. 2) Makroregion II, w którym znajdują się obszary wiej- 
territorial farms that require urgent organising of ownership aspects of the agrarian structure and the concept of the development of farm adequate to the challenges of the region. 3) Macroregion III, which includes rural areas dominated by medium-sized farms, representing minor evolutionary changes, but waiting for a boost from the state for the purpose of activation of production and for structural changes. The Institute of Agricultural and Food Economics presented a different concept, in which a typology for agricultural regions in Poland was developed, based on the direct surplus (inspired by the implementation of FADN system in Poland). Four regions were separated with the use of 7 statistical indicators determining the effects of production of agricultural farms. Different ways of separation of agricultural regions suggest that different approaches can be applied (different features of agriculture), moreover, different measures and indicators can be used to separate agricultural regions. According to Bański J. (2007)"... there are no coherent and homogeneous agricultural regions with the characteristics that would be generally accepted by the communities addressing these issues". The author of this publication suggests that separation of milk production areas should be based on a fairly standard indicator, possible to determine and well describing the issue of concentration of milk production, which is the density of dairy cows in particular poviats.

In 2010 the highest density of dairy cows was in north-eastern Poland (Figure 1). In particular in the following Provinces: Podlaskie, WarmińskoMazurskie, and the northern part of Mazowieckie Province. Upon thorough analysis of the issue of the density of cows in 2010, one should note that the poviats with the highest density of cows were skie o dominacji wielkoobszarowych gospodarstw rolnych wymagających pilnego porządkowania własnościowych aspektów struktury agrarnej oraz koncepcji rozwoju gospodarstwa rolnego adekwatnej do wyzwań tego regionu. 3) Makroregion III, w którym znajdują się obszary wiejskie o dominacji średniorolnych gospodarstw rolnych, znamionujących się słabą ewolucją przemian, ale oczekujących na państwowe impulsy do aktywizacji produkcyjnej oraz przemian strukturalnych. Inną koncepcję przedstawił Instytut Ekonomiki Rolnictwa i Gospodarki Żywnościowej, w której opracowano typologię regionów rolniczych w Polsce na podstawie nadwyżki bezpośredniej (inspiracją tego działania był wdrażany w Polsce system FADN). Wydzielając cztery regiony posłużono się 7 wskaźnikami statystycznymi wyznaczającymi efekty produkcyjne gospodarstw rolniczych. Różne sposoby wydzielania regionów rolniczych dają sygnał, że mogą być stosowane różne podejścia (różne cechy rolnictwa) oraz można wykorzystywać różne mierniki i wskaźniki do wydzielania regionów rolniczych. Bański J. (2007) stwierdza, że „...nie istniejq spójne i jednorodne regiony rolnicze określone cechami, które byłyby powszechnie akceptowane przez środowiska zajmujące się ta problematykq". Autor niniejszej publikacji proponuje w wyznaczaniu obszarów produkcji mleka oprzeć się o dość standardowy wskaźnik, ale możliwy do ustalenia i dość dobrze opisujący kwestię koncentracji produkcji mleka, jakim jest obsada krów mlecznych w poszczególnych powiatach.

Największą koncentracją chowu krów charakteryzowały się w 2010 roku obszary północno - wschodniej Polski (rysunek 1). Szczególnie województwo podlaskie, warmińsko-mazurskie i północna część województwa mazowieckiego. Przy-

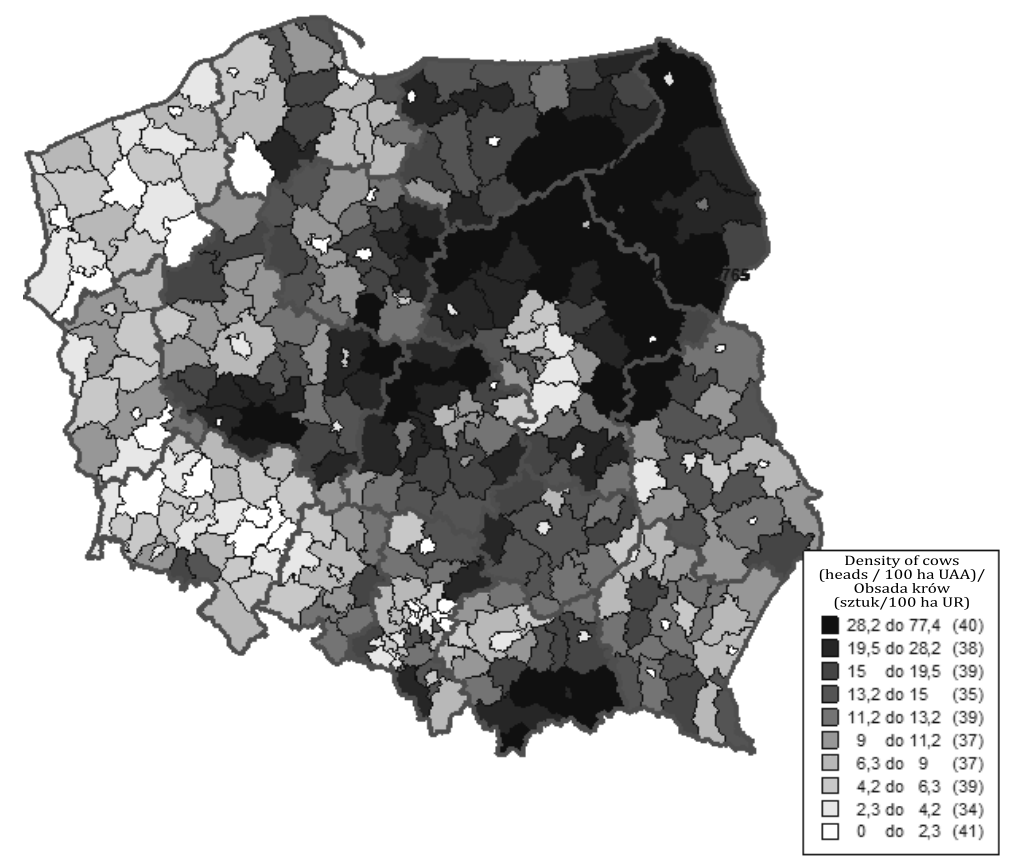

Figure 1. Density of cows per 100 ha of agricultural land (heads/100 ha UAA)

Rysunek 1. Obsada krów na 100 ha użytków rolnych (sztuk/100 ha UR)

Source: the author's own elaboration based on the data from the General Agricultural Census 2010. Źródło: opracowanie własne na postawie danych z Powszechnego Spisu Rolnego 2010. 
the following: Wysokomazowiecki (77.6 cows / 100 ha UAA), Zambrowski (69.8 cows / 100 ha UAA), Ostrołęcki (65.2 cows / 100 ha UAA), Kolneński (61.4 cows / 100 ha UAA), and Grajewski (55.7 cows / 100 ha UAA)

From among 14 rural poviats, which were separated in Podlaskie Province, as many as 8 were in the group of twenty poviats with the highest density of cows in Poland. The lowest density of cows in Podlaskie Province was in Hajnowski poviat. Apart from the three above-mentioned Provinces, a high density of cows was recorded in the poviats: Łowicki (48.7 cows/100 ha UAA), Gostyński (44.7 cows/ 100 ha UAA), Rypiński (41.2 cows/ 100 ha UAA) and Szczycieński (40.6 cows/ 100 ha UAA). It should also be noted that small number of animals per UAA was recorded in the following poviats: Oławski (0.9 cows/ 100 ha UAA), Wałecki $(1.0$ cows/ 100 ha UAA) and Wrocławski (1.1 cows/ 100 ha UAA).

Particularly interesting in terms of assessment of concentration of cows is the process of ongoing changes. The changes in the density of cows in the years 2002-2010 were analysed (on the basis of the data obtained from the General Agricultural Census). An eight-year analysis shows further polarisation of regions in terms of cattle breeding in Poland. It has been calculated (Figure 2) that the highest increase in the number of cows, and thus the density of cows, was recorded in the regions of Poland, where the highest density of cows was recorded in 2010. The leading Provinces were: Podlaskie, WarmińskoMazurskie and the northern part of Mazowieckie Province. Poviats with the highest density of cows were the following: Wysokomazowiecki $(+18.1$ cows/ 100 ha UAA), Koleński $(+197.4$ cows/ 100 ha UAA), Zambrowski (+16.7 cows/ 100 ha glądając się dokładniej obsadzie krów w 2010 roku należy stwierdzić, że najwyższą charakteryzowały się powiaty: wysokomazowiecki (77,6 krów/100 ha UR), zambrowski $(69,8$ krów/100 ha UR), ostrołęcki (65,2 krów/100 ha UR), kolneński (61,4 krów/100 ha UR) oraz grajewski (55,7 krów/100 ha UR).

$\mathrm{Z}$ wyodrębnionych 14 powiatów ziemskich w województwie podlaskim aż 8 znajdowało się w grupie dwudziestu powiatów charakteryzujących się najwyższą obsadą krów w Polsce. Z województwa podlaskiego najniższa obsada krów wystąpiła w powiecie hajnowskim. Poza trzema wskazanymi województwami wysoka obsade krów zanotowano $\mathrm{w}$ powiatach: łowickim (48,7 krów/100 ha UR), gostyńskim (44,7 krów/100 ha UR), rypińskim (41,2 krów/100 ha UR) oraz szczycieńskim (40,6 krów/100 ha UR). Zaznaczyć też należy, że śladowe ilości zwierząt w stosunku do powierzchni UR wystąpiły w powiatach: oławskim (0,9 krów/100 ha UR), wałeckim (1,0 krów/100 ha UR) i wrocławskim (1,1 krów/100 ha UR).

Szczególnie interesujący, w ocenie koncentracji chowu krów, jest proces dokonujących się zmian. Poddano analizie zmiany w obsadzie krów w latach 2002-2010 (na podstawie danych z Powszechnego Spisu Rolnego). W ośmiu analizowanych latach można zauważyć dalszą polaryzację obszarów Polski w chowie krów. Jak wynika z przeprowadzonych obliczeń (rysunek 2) największe zwiększenie pogłowia krów, a przez to obsady krów, miało miejsce w tych regionach Polski, w których zanotowano najwyższa obsadę krów w 2010 roku. Prym wiodły województwa: podlaskie, warmińsko-mazurskie i północna część województwa mazowieckiego. Powiatami, w których zanotowany największy przyrost obsady krów były: wysokomazowiecki $(+18,1$ krów/100 ha UR), koleński (+17,4 krów/100 ha UR), zambrowski

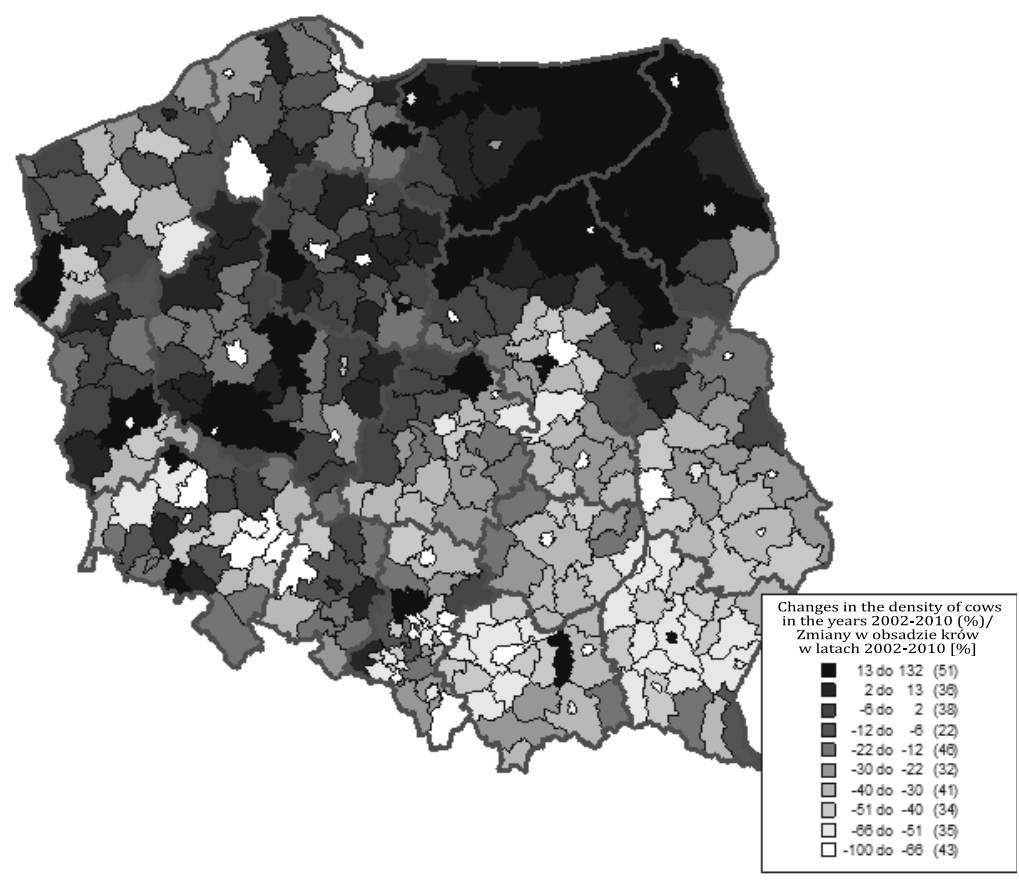

Figure 2. Changes in the density of cows in the years 2002-2010 (\%)

Rysunek 2. Zmiany w obsadzie krów w latach 2002-2010 (\%)

Source: the author's own elaboration based on the data from the General Agricultural Census 2010.

Źródło: opracowanie własne na postawie danych z Powszechnego Spisu Rolnego 2010. 
UAA), Ostrołęcki (+13.9 cows/ 100 ha UAA) and Przasnyski (13.5 cows/ 100 ha UAA). The greatest reduction in terms of cows breeding, and thus in the density of cows, was recorded in south-eastern Poland, especially in Małopolskie and Podkarpackie Province. The poviats, where the greatest reduction in terms of cows breeding was recorded during an eight-year analysis were the following: RopczyckoSędziszowski (-19.1 cows/ 100 ha UAA), Strzyżowski (-19.0 cows/ 100 ha UAA), Żywiecki (-17.9 cows/ 100 ha UAA), Myślenicki (-17.5 cows/ 100 ha UAA), Jasielski (-17.3 cows/ 100 ha UAA), and Tatrzański $(-17.2$ cows/ 100 ha of UAA). The percentage reduction in density of cows in the six abovementioned poviats ranged from $31 \%$ (Tatrzański) to 67\% (Żywiecki).

The overall assessment of concentration of dairy cows breeding in particular poviats (the density of cows and its changes in the years 2002-2010) can be based on a relative point efficiency indicator (described in the methodological section). The highest indicator, taking into account the density of cows and its changes, was in Wysokomazowiecki poviat. The upper percentile ( $10 \%$ of poviats) included:

1. almost the entire Podlaskie Province (excluding Hajnowski and Sokolski poviats);

2. northern part of Mazowieckie Province (poviats in the following order: Ostrowski Mazowiecki, Przasnyski, Mławski, Żuromiński, Makowski, Sokołowski, Sierpecki, Węgrowski, Pułtuski);

3. the south-eastern part of Warmińsko-Mazurskie Province (poviats in the following order: Szczycieński, Piski, Mrągowski, and Ełcki);

4. three poviats from Wielkopolskie Province: Gostyński, Krotoszyński and Kościański;

5. two poviats from Kujawsko-Pomorskie Province: Rypiński and Radziejowski;

6. Łowicz Poviat from the Łódzkie Province.

Podkarpackie Province and the north-western part of Małopolskie Province appear to be leaders when analysing the lower percentile of poviats, where the lowest density of cows and its gradual reduction were recorded.

\section{The main factors determining the regional differentiation of milk production in Poland}

The research conducted by the author of the article among the employees of communes dealing with the issue of agriculture in 2012 indicated that the main factors, which determined the development of agricultural farms in terms of milk production, were the following (Table 1):

a) Positive historical conditions. Milk production in dairy farms from a separate region has always been an important activity. In the 1970s, under the influence of the policy implemented at that time, investment activities were carried out by farmers on many farms (mainly construction of cowsheds) taking advantage of favourable conditions for loans. The farms were oriented at milk production, which forced further development in this branch of production.
(+16,7 krów/100 ha UR), ostrołęcki ( $+13,9$ krów/100 ha UR) oraz przasnyski (13,5 krów/100 ha UR). Największe ograniczenia chowu krów, a przez to obsady miały miejsce w Polsce południowo - wschodniej, szczególnie w województwach małopolskim i podkarpackim. Powiatami charakteryzującymi się największym ograniczeniem chowu krów $\mathrm{w}$ analizowanych ośmiu latach były: ropczycko-sędziszowski (-19,1 krów/100 ha UR), strzyżowski (-19,0 krów/100 ha UR), żywiecki (-17,9 krów/100 ha UR), myślenicki (-17,5 krów/100 ha UR), jasielski (-17,3 krów/100 ha UR) oraz tatrzański (-17,2 krów/100 ha UR). Procentowo zmniejszenie obsady w wymienionych sześciu powiatach wahało się od $31 \%$ (tatrzański) do 67\% (żywiecki).

Do łącznej oceny koncentracji chowu krów mlecznych w poszczególnych powiatach (obsady krów oraz jej zmian w latach 2002-2010) może posłużyć m.in. wskaźnik względnej efektywności punktowej (opis w części metodycznej). Wskaźnik ten, uwzględniający obsadę krów i jej zmiany, najwyższy był w powiecie wysokomazowieckim. Do górnego percentyla (10\% powiatów) należało:

1. prawie całe województwo podlaskie (bez powiatów hajnowskiego i sokólskiego);

2. północna część województwa mazowieckiego (powiaty w kolejności: ostrowski mazowiecki, przasnyski, mławski, żuromiński, makowski, sokołowski, sierpecki, węgrowski, pułtuski);

3. południowo-wschodnia część województwa warmińsko-mazurskiego (powiaty w kolejności: szczycieński, piski, mrągowski, ełcki);

4. trzy powiaty z województwa wielkopolskiego: gostyński, krotoszyński i kościański;

5. dwa powiaty z województwa kujawsko-pomorskiego: rypiński i radziejowski;

6. powiat łowicki z województwa łódzkiego.

Analizując dolny percentyl powiatów, charakteryzujących się najniższą obsadą krów i jej sukcesywnym zmniejszaniem wynika, że prym widzie województwo podkarpackie oraz północno - zachodnia część województwa małopolskiego.

\section{Główne czynniki wpływające na regionalne zróż- nicowanie produkcji mleka w Polsce}

Z przeprowadzonych przez autora artykułu badań wśród pracowników gmin zajmujących się problematyką rolnictwa w 2012 roku wynikało, że wśród głównych czynników, które wpłynęły na rozwój gospodarstw rolniczych w kierunku produkcji mleka były: (tabela 1 )

a) Pozytywne uwarunkowania historyczne. Produkcja mleka w gospodarstwach z wydzielonego regionu zawsze była istotną działalnością. W latach 70-tych, pod wpływem wówczas realizowanej polityki wiele gospodarstw przeprowadziło działania inwestycyjne (głównie budowa obór dla krów) w oparciu o atrakcyjne kredyty. Gospodarstwa zostały ukierunkowane na produkcję mleka, co wymuszało dalszy rozwój w tym kierunku produkcji. 
b) There was no alternative to another activity. Poor soil quality, lack of market for other agricultural products (among others, potatoes), lack of work outside the farm forced farmers (often despite unfavourable conditions for the production of milk) to continue the activity they had started. This process was particularly visible at the beginning of the 1990s (after the introduction of a market-oriented economy) when the prices of milk in the milk purchasing centre decreased significantly. Throughout Poland, there has been a reduction in the number of cows, while in some parts of the "region, where milk production was developed" there was an increase in production (especially in the former Łomża Province).

c) Initiatives of the management of local dairies. The management in certain dairies, after the introduction of a market-oriented economy, have undertaken various activities to maintain (and even increase) milk production in dairy farms. A good example was OSM Piątnica, in which a new product was introduced (cottage cheese) and at the same time farmers were motivated to improve the quality of the milk they supplied. Specific financial resources were activated for low-interest loans for farmers to purchase milk coolers, milking machines and dairy cows. An option to provide farmers in the dairy with disinfectants for udders, ointments and balms used in the prevention of udder diseases and spare parts for milking machines. Moreover, large-scale training activities were organised. In addition to these activities, a specific way of calculating the price of milk supplied to the dairy was applied, which influenced the attitude of farmers. Partial elements of the total price of milk were introduced. Taking these actions in a timely manner influenced the process of changes in milk production on farms.

d) Training and implementation programs. A number of programs for local community leaders regarding modern milk production were implemented (especially in the 90's). The so-called "Turoślański program" was a significant activity for the representatives of local authorities. It was implemented in three stages. The first was conducted in the years 1991-1992 and comprised 13 farms located in the Turośl Commune. The next stage implemented in the years 19931995 comprised 50 farms and the last stage was the widest-ranging because more than 200 farms were involved in it from the then-existing five Provinces of north-eastern Poland (Białystok, Ciechanów, Olsztyn, Ostrołęka, and Suwałki). The first stage of the implemented project was particularly important for the development of milk production in the region. 13 farmers selected for the project participated, together with their wives, in a 2-week study trip to the Netherlands, where they learned about the functioning of modern dairy farms. After returning to Poland, they modernized or built cowsheds, purchased machines for preparing b) Brak alternatywy dla innej działalności. Słaba jakość gleb, brak zbytu dla innych produktów rolniczych (m.in. ziemniaków), brak pracy poza gospodarstwem zmuszała rolników (często mimo niekorzystnej koniunktury na mleko) do kontynuowania rozpoczętej działalności. Szczególnie proces ten uwidocznił się na początku lat 90-tych (po urynkowieniu gospodarki), w których ceny mleka w skupie bardzo wyraźnie zmniejszyły się. W całej Polsce nastąpiła redukcja pogłowia krów, natomiast w niektórych częściach „regionu zdefiniowanego jako rozwijający produkcję mleka" nastąpiło zwiększenie produkcji (szczególnie w byłym województwie łomżyńskim).

c) Inicjatywy kierownictwa lokalnych mleczarni. Niektóre mleczarnie, po urynkowieniu gospodarki, podjęły różnego rodzaju działania zmierzające do utrzymania (a nawet zwiększania) produkcji mleka w gospodarstwach rolniczych. Dobrym przykładem była OSM Piątnica, w której wprowadzono nowy produkt (serek wiejski) i jednocześnie motywowano rolników do poprawy jakości dostarczanego mleka. Uruchomiono określone środki finansowe na niskoprocentowe pożyczki dla rolników na zakup schładzalników mleka, dojarek i krów mlecznych. Wprowadzono możliwość zaopatrywania się rolników w mleczarni w preparaty dezynfekcyjne do wymion, maści i balsamy stosowane w profilaktyce schorzeń wymion oraz części zamienne do dojarek. Dodatkowo uruchomiono, na szeroką skalę, działalność szkoleniową. Oprócz tych działań zaczęto oddziaływać na rolników sposobem kalkulowania ceny za dostarczane do mleczarni mleko. Zaczęto ustalać cząstkowe elementy sumarycznej ceny za mleko. Podjęcie tych działań we właściwym czasie miało wpływ na proces zmian $\mathrm{w}$ produkcji mleka w gospodarstwach rolniczych.

d) Programy szkoleniowo - wdrożeniowe. Uruchomiono szereg programów dla liderów lokalnej społeczności, dotyczących nowoczesnej produkcji mleka (szczególnie w latach 90-tych). Mocno w pamięci przedstawicieli władz lokalnych utkwił tzw. „program turoślański”. Realizowany był on w trzech etapach. Pierwszy w latach 19911992 i obejmował 13 gospodarstw zlokalizowanych w gminie Turośl. Kolejny etap realizowany w latach 1993-1995 obejmował swym zasięgiem już 50 gospodarstw i ostatni o najszerszym zasięgu bo uczestniczyło w nim ponad 200 gospodarstw z ówczesnych pięciu województw Polski północno-wschodniej (białostockie, ciechanowskie, olsztyńskie, ostrołęckie, suwalskie). Szczególnie istotnym dla rozwoju produkcji mleka $\mathrm{w}$ regionie był etap pierwszy realizowanego projektu. 13 rolników wybranych do projektu uczestniczyło, wspólnie z żonami w 2-u tygodniowym studyjnym wyjeździe do Holandii, gdzie poznawali funkcjonowanie nowoczesnych gospodarstw ukierunkowanych na produkcję mleka. Po przyjeździe do Polski, częściowo z uzy- 
silage partly with the use of the subsidies they obtained for the implementation of the project, and partly with the use of preferential credits. It was a clear impulse for the local community ${ }^{1}$.

e) Opportunities to work abroad. The development of milk production requires undertaking investment activities (modernization or construction of livestock buildings, purchase of machinery and equipment, etc.). In the 1990s, a significant number of inhabitants from the then Łomża Province (mainly from the Siemiatycze region) left their homes to work in Western European countries and in the USA. Then they invested the money they had earned in Poland, often in their farms.

f) A favourable economic situation for milk producers after the accession to EU. A significant number of farms from the region defined as "the region where milk production was developed" at the time of Poland's accession to the EU carried out a commercial production of milk. The favourable economic situation allowed for further development of farms.

g) Access to EU structural funds. The relatively high commerciality of farms (previously implemented investments) made it possible to take advantage of EU structural funds. They allowed mainly for an upgrading of the machines used. skanych dotacji na realizację projektu, częściowo z kredytów preferencyjnych, zmodernizowali lub wybudowali obory, zakupili maszyny do sporządzania sianokiszonki. Dało to wyraźny impuls dla społeczności lokalnej ${ }^{1}$.

e) Możliwości wyjazdu do pracy za granicę. Rozwijanie produkcji mleka wymaga działań inwestycyjnych (modernizacja lub budowa budynków inwentarskich, zakup maszyn i urządzeń, itp.). W latach 90-tych, znaczna liczba mieszkańców z ówczesnego województwa łomżyńskiego (głównie z okolic Siemiatycz) wyjeżdżała do pracy do krajów Europy Zachodniej i USA. Zarobione pieniądze były inwestowane w Polsce, często w gospodarstwach rolniczych.

f) Korzystna koniunktura na mleko po wejściu do UE. Znaczna liczba gospodarstw z regionu zdefiniowanego jako „rozwijający produkcje mleka" w momencie przystapienia Polski do UE prowadziła towarową produkcję mleka. Korzystna koniunktura pozwalała na dalszy rozwój gospodarstw.

g) Dostęp do funduszy strukturalnych UE. Względnie wysoka towarowość gospodarstw (wcześniej realizowane inwestycje) umożliwiły korzystanie z funduszy strukturalnych UE. Głównie pozwoliły one na odnowienie parku maszynowego.

Table 1. The main external factors which contribute to the development of farms*

Tabela 1. Główne impulsy zewnętrzne przyczyniające się do rozwoju gospodarstw*

\begin{tabular}{|c|c|c|c|c|c|c|}
\hline \multirow{2}{*}{ Specification / Wyszczególnienie } & \multicolumn{5}{|c|}{$\begin{array}{l}\text { Percentage of indications / } \\
\text { Odsetek wskazań }\end{array}$} & \multirow{2}{*}{$\begin{array}{c}\text { In total / } \\
\text { razem }\end{array}$} \\
\hline & 1 & 2 & 3 & 4 & 5 & \\
\hline $\begin{array}{l}\text { Positive historical conditions / } \\
\text { Pozytywne uwarunkowania historyczne }\end{array}$ & 24 & 21 & 29 & 19 & 7 & 100 \\
\hline $\begin{array}{l}\text { No alternative to other activities / } \\
\text { Brak alternatywny dla innej działalności }\end{array}$ & 22 & 28 & 20 & 10 & 20 & 100 \\
\hline $\begin{array}{l}\text { Initiatives of the management of local dairies / } \\
\text { Inicjatywy kierownictwa lokalnych mleczarni }\end{array}$ & 17 & 13 & 20 & 15 & 21 & 86 \\
\hline $\begin{array}{l}\text { Training and implementation programs / } \\
\text { Programy szkoleniowo - wdrożeniowe }\end{array}$ & 12 & 11 & 18 & 15 & 22 & 78 \\
\hline $\begin{array}{l}\text { Opportunities to work abroad / } \\
\text { Możliwości wyjazdu do pracy za granicą }\end{array}$ & 2 & 2 & 5 & 10 & 5 & 24 \\
\hline $\begin{array}{l}\text { A favourable economic situation for milk producers after the accession to EU / } \\
\text { Korzystna koniunktura na mleko po wejściu do UE }\end{array}$ & 10 & 15 & 5 & 15 & 5 & 50 \\
\hline $\begin{array}{l}\text { Access to EU structural funds / } \\
\text { Dostęp do funduszy strukturalnych UE }\end{array}$ & 13 & 10 & 3 & 16 & 20 & 62 \\
\hline
\end{tabular}

* respondents indicated "impulses”, arranging them in order of importance (1- the most important, 5 - the least important)

* respondenci wskazywali „impulsy”, szeregując je od najważniejszych (1- najważniejszy, 5 - najmniej ważny)

Source: the author's own elaboration based on surveys.

Źródło: opracowanie własne na podstawie badań ankietowych.

\footnotetext{
${ }^{1}$ The Polish-Dutch Project on the development of private dairy farms was based, among others, on the principle of intensive consulting of "practical cooperation" type. To achieve such cooperation, advisors were hired with personal experience and extensive knowledge of practical and modern ways of running dairy farms. More information on the implementation of this project can be found in the work: Witkowski M., 1997: Efektywność ekonomiczno-organizacyjna I etapu Projektu Rozwoju Prywatnych Gospodarstw Mlecznych w Turośli, [in] Postęp techniczny a organizacja gospodarstw rolniczych, edited by Maniecki F., Wydawnictwo SGGW, Warsaw.
}

\footnotetext{
${ }^{1}$ Polsko-holenderski Projekt Rozwoju Prywatnych Gospodarstw Mlecznych opierał się m.in. na zasadzie intensywnego doradztwa typu „praktycznego współdziałania”. Aby osiągnąć takie współdziałanie zatrudniono doradców posiadających osobiste doświadczenie i rozległą wiedzę na temat praktycznego, nowoczesnego prowadzenia gospodarstw mlecznych. Więcej informacji na temat realizacji tego projektu można znaleźć w pracy: Witkowski M., 1997: Efektywność ekonomiczno-organizacyjna I etapu Projektu Rozwoju Prywatnych Gospodarstw Mlecznych w Turośli, [w] Postęp techniczny a organizacja gospodarstw rolniczych, pod redakcją Manieckiego F., Wydawnictwo SGGW, Warszawa
} 
Summing up the presented factors, it can be clearly stated that the consistent pursuit of further development of milk production in farms by the local community (sometimes despite unfavourable external conditions) and taking advantage of the emerging opportunities over many years were the main cause of the existing situation.

Despite the development of dairy farms in a separated region, a number of barriers have often been highlighted, which may constitute barriers to the further development of milk production in farms from this separated region. These were: 1) the lack of the possibility to buy land, 2) growing agri-environmental requirements and the method of calculating direct subsidies 3) lack of own financial resources for the development of farms oriented at milk production, 4) dense development of the village (no possibility to construct livestock buildings), 5) lack of successors in agricultural farms.

Evaluation of assistance programs supporting the development of dairy farms

Milk production in agricultural farms is a difficult activity, it has its unique character and there are consequences resulting from it. From the economic and organizational point of view, the most important features of milk production in agricultural farms (as compared to other agricultural activities) include: 1) high labour intensity and capital intensity of production in comparison to other agricultural activities, 2) clear connection between milk production and crop production on the farm, 3) difficulty to obtain the desired hygienic quality of milk, 4) necessity of cooperation between the farmer (producer) and the milk processor (dairy). The above-mentioned obstacles, if they are not compensated by the price of milk or specific subsidies, they do not encourage farmers to conduct (continue) this activity. In this context, the following question arises: To what extent the assistance programs intended for farms under RDP 2007-2013 and RDP 2014-2020 promote the development of dairy farms? According to the reporting data of ARMA by the end of 2014 under the measure 121. "Modernization of agricultural holdings" (the most important activity affecting the development of farms) the total amount of completed investments was over PLN 37 billion (Table 2). It was a measure that all farmers undertaking investment activities could benefit from - not only dairy farms. Under the analysed measure mainly investments for the purchase of mobile equipment were made, they constituted $89 \%$ of all investments. The following investments had the greatest share in all investments for the purchase of mobile equipment: in agricultural machinery and equipment as well as means of transport (different from tractors) for crop production (47\% of investment in mobile equipment), and then - purchase of farm tractors (36\% of investments in agricultural equipment), machines, devices and equipment for animal production, including software, which amounted to $13 \%$ of investment in mobile equipment, and elements of equipment, elements of machines and tools, additional equipment, including software, had the smallest share (4\%) in all investments in mobile equipment.
Reasumując przedstawione czynniki, można wyraźnie stwierdzić, że konsekwentne postępowanie lokalnej społeczności w kierunku rozwijania produkcji mleka w gospodarstwach rolniczych (czasami mimo niekorzystnych warunków zewnętrznych) i wykorzystywanie pojawiających się szans $\mathrm{w}$ przeciągu wielu lat było główną przyczyną istniejącej sytuacji.

Mimo rozwoju gospodarstw mlecznych w wydzielonym regionie często podkreślano szereg barier, które mogą stanowić bariery $\mathrm{w}$ dalszym rozwoju produkcji mleka w gospodarstwach $\mathrm{z}$ wydzielonego regionu. Były to: 1) brak możliwości zakupu ziemi, 2) rosnące wymagania rolnośrodowiskowe i sposób naliczania dopłat bezpośrednich 3) brak własnych środków finansowych na rozwój gospodarstw w kierunku produkcji mleka, 4) zwarta zabudowa wsi (brak możliwości budowy budynków inwentarskich), 5) brak następców w gospodarstwach rolniczych.

Ocena programów pomocowych wspomagających rozwój gospodarstw mlecznych

Produkcja mleka w gospodarstwach rolniczych jest trudną działalnością, ma swoją specyfikę i wynikające z niej konsekwencje. Z punktu widzenia ekonomiczno-organizacyjnego do najważniejszych cech produkcji mleka w gospodarstwach rolniczych (na tle innych działalności rolniczych) można zaliczyć: 1) wysoką pracochłonność i kapitałochłonność produkcji w stosunku do innych działalności rolniczych, 2) wyraźne powiązanie produkcji mleka z produkcją roślinną w gospodarstwie rolniczym, 3) trudną do uzyskania pożądanąjakość higieniczną mleka, 4) konieczność współpracy rolnika (producenta) z przetwórcą mleka (mleczarnią). Wymienione utrudnienia jeśli nie są rekompensowane cena mleka lub określonymi subwencjami nie zachęcają rolników do prowadzenia (kontynuowania) tej działalności. W tym kontekście pojawia się pytanie: $\mathrm{W}$ jakim zakresie programy pomocowe kierowane do gospodarst $w \mathrm{w}$ ramach PROW 2007-2013 oraz PROW 2014-2020 wspierają rozwój gospodarstw mlecznych? Jak wynika z danych sprawozdawczych ARiMR do końca 2014 r. w ramach działania 121. „Modernizacja gospodarstw rolnych” (najważniejsze działanie wypływające na rozwój gospodarstw rolniczych) łączna kwota zrealizowanych inwestycji wynosiła ponad $37 \mathrm{mld}$ zł (tabela 2). Było to działanie, z którego mogli skorzystać wszyscy rolnicy podejmujący działania inwestycyjne- nie tylko gospodarstwa prowadzące produkcję mleka. W ramach analizowanego podziałania głównie realizowano inwestycje na zakup sprzętu ruchomego, które stanowiły 89\% wszystkich inwestycji. Wśród inwestycji na zakup sprzętu ruchomego największy udział miały inwestycje w maszyny, urządzenia i narzędzia rolnicze oraz środki transportu (inne niż ciągniki) do produkcji roślinnej (47\% inwestycji w sprzęt ruchomy), a następnie - zakup ciągników rolniczych (36\% inwestycji w sprzęt rolniczy), maszyny, narzędzia, urządzenia i wyposażenie do produkcji zwierzęcej, w tym oprogramowanie stanowiły 13\% inwestycji w sprzęt ruchomy, a najmniejszy udział $4 \%$ inwestycji w sprzęt ruchomy stanowiły elementy wyposażenia, elementy maszyn, narzędzi, wyposażenie dodatkowe, w tym oprogramowanie. 
Table 2. Types of investments carried out under the measure “Modernization of agricultural holdings” in the years 2007-2013 in Poland Tabela 2. Rodzaje przeprowadzonych inwestycji w ramach działania „Modernizacja gospodarstw rolnych” w latach 2007-2013 w Polsce

\begin{tabular}{|c|c|c|c|c|}
\hline Type / Тур & \begin{tabular}{|c|}
$\begin{array}{c}\text { The number of } \\
\text { completed types } \\
\text { of investments } \\
\text { under operation / } \\
\text { Liczba zrealizo- } \\
\text { wanych typów in- } \\
\text { westycji w ramach } \\
\text { operacji }\end{array}$ \\
\end{tabular} & $\begin{array}{l}\text { Unit of } \\
\text { measure- } \\
\text { ment / } \\
\text { Jedn. } \\
\text { miary }\end{array}$ & \begin{tabular}{|} 
Total eligible \\
expenditure \\
(PLN) / \\
Całkowite wydat- \\
ki kwalifikowal- \\
ne (zł)
\end{tabular} & $\begin{array}{c}\text { Total investment } \\
\text { value (PLN) (eligible } \\
\text { and ineligible) / } \\
\text { Całkowita wartość } \\
\text { inwestycji (zł) (kwali- } \\
\text { fikowalne i niekwali- } \\
\text { fikowalne) }\end{array}$ \\
\hline $\begin{array}{l}\text { The surface area of built or modernized production } \\
\text { buildings, including: / } \\
\text { Powierzchnia wybudowanych lub zmodernizowa- } \\
\text { nych budynków produkcyjnych, w tym: }\end{array}$ & 3727 & \multirow{6}{*}{$\left(m^{2}\right)$} & 675732639.09 & 829528507.98 \\
\hline - cowsheds / obory & 536 & & 105705528.80 & 130715808.90 \\
\hline - piggeries / chlewnie & 275 & & 37578450.96 & 46307501.52 \\
\hline $\begin{array}{l}\text { - other buildings intended for livestock /inne } \\
\text { budynki przeznaczone na inwentarz żywy }\end{array}$ & 279 & & 61573648.50 & 75757671.88 \\
\hline - greenhouses (including equipment) & 273 & & 82252839.46 & 97060827.33 \\
\hline $\begin{array}{l}\text { - other farm buildings / pozostałe budynki } \\
\text { gospodarcze }\end{array}$ & 2364 & & 388622171.37 & 479686698.35 \\
\hline $\begin{array}{l}\text { Surface area of manure pads / } \\
\text { Powierzchnia płyt obornikowych }\end{array}$ & 685 & $\left(\mathrm{~m}^{2}\right)$ & 20414241.17 & 25887833,62 \\
\hline $\begin{array}{l}\text { The volume of liquid manure and slurry tanks / } \\
\text { Objętość zbiorników na gnojówkę i gnojowicę }\end{array}$ & 843 & $\left(\mathrm{~m}^{3}\right)$ & 38350468.46 & 47058152.27 \\
\hline $\begin{array}{l}\text { The amount of purchased mobile equipment, including: / } \\
\text { Liczba zakupionego sprzętu ruchomego, w tym: }\end{array}$ & 108597 & \multirow{5}{*}{ (item) } & 15245830570.57 & 18588582546.64 \\
\hline - farm tractors / ciągniki rolnicze & 39384 & & 6924911401.52 & 84779222222.72 \\
\hline $\begin{array}{l}\text { - agricultural machinery, agricultural equipment } \\
\text { and means of transport (different from tractors) } \\
\text { for crop production, including software / ma- } \\
\text { szyny rolnicze, narzędzia rolnicze, urządzenia } \\
\text { oraz środki transportu (inne niż ciągniki) do } \\
\text { produkcji roślinnej, w tym oprogramowanie }\end{array}$ & 51277 & & 7037782744.91 & 8580168242.95 \\
\hline $\begin{array}{l}\text { - machinery, tools, equipment and equipment for } \\
\text { animal production, including software / maszy- } \\
\text { ny, narzędzia, urządzenia i wyposażenie do pro- } \\
\text { dukcji zwierzęcej, w tym oprogramowanie }\end{array}$ & 13703 & & 1074416238.31 & 1308023749.67 \\
\hline $\begin{array}{l}\text { - elements of equipment, elements of machines } \\
\text { and tools, additional equipment, including soft- } \\
\text { ware / elementy wyposażenia, elementy ma- } \\
\text { szyn, narzędzi, wyposażenie dodatkowe, w tym } \\
\text { oprogramowanie }\end{array}$ & 4233 & & 208720185.83 & 252468331.30 \\
\hline $\begin{array}{l}\text { The amount of purchased computer equipment / } \\
\text { Liczba zakupionego sprzętu komputerowego }\end{array}$ & 760 & (item) & 3163292.59 & 3904498.29 \\
\hline $\begin{array}{l}\text { Elements of technical infrastructure, including: / } \\
\text { Elementy infrastruktury technicznej, w tym: }\end{array}$ & - & - & - & - \\
\hline $\begin{array}{l}\text { - manoeuvring areas / powierzchnia placów } \\
\text { manewrowych }\end{array}$ & 4201 & $\left(\mathrm{~m}^{2}\right)$ & 573914777.80 & 703317228.32 \\
\hline $\begin{array}{l}\text { - the length of access roads / długość dróg } \\
\text { dojazdowych }\end{array}$ & 256 & (m) & 17019601,82 & 20476220.11 \\
\hline $\begin{array}{l}\text { The area of established/modernized orchards or } \\
\text { perennial plantations / } \\
\text { Powierzchnia założonych/zmodernizowanych sa- } \\
\text { dów lub plantacji wieloletnich }\end{array}$ & 1959 & (ha) & 189189088.92 & 206574478.63 \\
\hline $\begin{array}{l}\text { The surface area of built or modernized buildings } \\
\text { used for production and direct sale on farms / } \\
\text { Powierzchnia wybudowanych lub zmodernizowa- } \\
\text { nych obiektów służących produkcji i sprzedaży } \\
\text { bezpośredniej w gospodarstwach rolniczych }\end{array}$ & 549 & $\left(\mathrm{~m}^{2}\right)$ & 69488431.47 & 84641541.20 \\
\hline
\end{tabular}

Source: the author's own elaboration based on: The Report on the implementation of the Rural Development Programme for 2007-2013 for the year 2014, Ministry of Agriculture and Rural Development, Report No. 8, Warsaw 2014.

Źródło: Opracowanie własne na podstawie: Sprawozdanie z realizacji Programu Rozwoju Obszarów Wiejskich na lata 20072013 za 2014 r., Ministerstwo Rolnictwa i Rozwoju Wsi, sprawozdanie nr 8, Warszawa 2014. 
Investments in manoeuvring areas (3.5\%) were in the second place in terms of the number of completed investments, which may indicate that farmers showed interest in hardening the surface in their properties. Investments in production buildings (3\% of all investments) were in the third place. Farmers were far less interested in investments related to the establishment or modernization of orchards or perennial plantations (1.6\%), liquid manure and slurry tanks $(0.7 \%)$, the purchase of computer equipment $(0.6 \%)$, manure pads $(0,56 \%)$.

Such a structure of investment activities may indicate that in case of Polish farms there was a need to replace the production facilities (Hornowski 2015). The level of wear and tear of the fixed assets on farms in Poland in 2004 amounted to $70.3 \%$ (Zwolak 2007), besides, the quality of these assets was poor (Dzun 2003). It was therefore necessary to replace old equipment with a new one that is more efficient, enables an opportunity to implement new production technologies, and also increases work efficiency.

It should also be emphasized that procedures (legal framework and preparation of documents) for obtaining support for investments in mobile equipment were relatively easy for farmers, which meant that they were not concerned about the failure to fulfil the conditions and the need to return EU funds. In case of investments in production buildings, the procedure of settlement of the requests was more complicated. The production facility had to be built in accordance with the construction plan and the dimensions contained in this plan. During the settlement and control, the farmer had to submit a very large number of documents, including invoices for materials, components or for services rendered. The difficulty during the settlement of the request was very small tolerance margin in the construction of the facility as compared to the construction plan. During the construction, deviations from the plan often occurred, they had to be corrected and then reported in the annex to the request. The purchase of elements of a particular brand and of a particular manufacturer, declared in the request, was binding, otherwise, each change of the declared plan required submission of annex to the request. This resulted in the preparation of a very large number of documents during the implementation of an investment. During the next programming period (2014-2020), the Rural Development Program was also implemented (the next edition), and the sub-measure "Support for investments in agricultural holdings" under the operation "Modernization of agricultural holdings". The program enabled farmers to obtain a higher financial support for investments in terms of construction of livestock buildings, including cowsheds. The maximum amount of subsidy has been established at the level of PLN 500,000. This is a good move which can contribute to sustainable investments in the form of buildings on the farms oriented at milk production.

While indicating programs stimulating the development of dairy farms, attention should be paid to the system of direct subsidies. The one that had
Drugie miejsce pod względem liczby przeprowadzonych inwestycji zajmowały inwestycje w place manewrowe $(3,5 \%)$, co może wskazywać na to, że rolnicy wykazywali zainteresowanie utwardzaniem powierzchni swoich posiadłości. Trzecie miejsce zajmowały inwestycje w budynki produkcyjne (3\% wszystkich inwestycji). Znacznie mniejsze zainteresowanie wśród rolników dotyczyło inwestycji związanych z zakładaniem lub modernizowaniem sadów bądź plantacji wieloletnich (1,6\%), zbiornikami na gnojówkę i gnojowicę $(0,7 \%)$, zakupem sprzętu komputerowego $(0,6 \%)$, płytami obornikowymi $(0,56 \%)$.

Taka struktura działań inwestycyjnych może świadczyć o tym, że w polskich gospodarstwach rolniczych istniała potrzeba wymiany zaplecza produkcyjnego (Hornowski 2015). Stopień zużycia środków trwałych $w$ gospodarstwach rolniczych w Polsce w 2004 r. wynosił 70,3\% (Zwolak 2007), poza tym jakość tych środków trwałych była niska (Dzun 2003). Istniała więc konieczność zastępowania starego sprzętu, nowym, który jest bardziej wydajny, daje możliwość wdrażania nowych technologii produkcji, a także przyczynia się do poprawy wydajności pracy.

Trzeba też podkreślić, że procedury (uwarunkowania prawne i konstrukcja dokumentów) uzyskania wsparcia na inwestycje w środki ruchome były dla rolników stosunkowo proste, co spowodowało, że nie bali się oni o niespełnienie warunków i konieczność zwrócenia środków unijnych. W przypadku inwestycji w budynki produkcyjne procedura rozliczenia wniosku była bardziej skomplikowana. Obiekt produkcyjny musiał być wybudowany zgodnie z planem budowy i wymiarami zawartymi w tym planie. Podczas rozliczenia i kontroli rolnik musiał przedstawić bardzo dużą liczbę dokumentów, m.in. faktury na materiały, komponenty czy za wykonane usługi. Utrudnieniem przy rozliczaniu wniosku był mały, dopuszczalny margines błędu przy budowie obiektu $\mathrm{w}$ porównaniu z planem budowy. $\mathrm{W}$ trakcie budowy często pojawiały się odchylenia od planu, które musiały być poprawione, a następnie zgłoszone $\mathrm{w}$ aneksie do wniosku. Zadeklarowany we wniosku zakup elementów wybranej marki i producenta był wiążący, w przeciwnym wypadku do wniosku przy każdej zmianie zadeklarowanego planu konieczne było złożenie aneksu do wniosku. To powodowało tworzenie bardzo dużej liczby dokumentów w trakcie przeprowadzania inwestycji. W kolejnym okresie programowania (2014-2020) także został uruchomiony Program Rozwoju Obszarów Wiejskich (kolejna edycja), a w nim wprowadzone poddziałanie „Wsparcie inwestycji w gospodarstwach rolnych" w ramach operacji „Modernizacja gospodarstw rolnych”. Wprowadzono w nim możliwość uzyskania większego dofinansowania inwestycji w przypadku budowy budynków inwentarskich, $\mathrm{w}$ tym obór dla bydła. Maksymalna kwota dofinansowania została określona na 500 tys. zł. Jest to dobry kierunek zmian, który może przyczynić się do trwałych inwestycji $\mathrm{w}$ postaci budynków w gospodarstwach ukierunkowanych na produkcję mleka.

Wskazując programy pomocowe stymulujące rozwój gospodarstw mlecznych należy zwrócić uwagę 
been adopted in Poland and was applicable by 2014 did not promote the support for milk production in any particular way. The situation began to slightly change in 2015 when the Sejm of the Republic of Poland adopted an Act "on payments in the framework of direct support system" introducing: single area payment, greening payment, payment for young farmers, additional payment and production payments (payments related to the area of some crops and to the number of owned animals of certain species) (Journal of Laws from 2015, item 308). In Article 16.1. of the above Act, "the payments related to animals" were introduced for the first time and they apply to the following species: domestic cattle, domestic sheep and domestic goat. These payments refer to production - the higher the number of animals, the higher subsidies the farmer will receive. However, somerestrictions have been introduced with reference to the number of animals covered by the payments. In the case of cows, a minimum number of 3 cows was established, while the maximum number, to which subsidies applied, amounted to 30 . In the case of other groups of bovine animals (calves, heifers, etc.) the same limits have been introduced (3-30 heads). The amendment to the Act on direct support payments of October 21, 2016, (enacted on December 15, 2016) introduced changes, among others, concerning the upper limit of the number of cows and other bovine animals supported by the subsidies - 20 head of cattle were proposed (Journal of Laws from 2016, item 2037). In 2015, the amount of PLN 644,888.527 was allocated for direct subsidies for breeding of cows, and PLN 720,233.480 for breeding of other bovine animals. It was respectively PLN 314.20 and PLN 258.97 per one head. It should be emphasized that the idea of supporting farms breeding cows is good, but the designated limitations on the number of livestock are incomprehensible. There should be a shift in the number of subsidised breeding of 3-20 cows to the higher number - there is no economic justification (in the context of the development of this type of production) for supporting farms keeping 3 cows. The minimum size of the herd, which may encourage the farmer to consider the development of this activity (an increase of production) in Poland in 2016 was at the level of 10 head of cattle. Providing financial support to the farmer keeping this herd can encourage the farmer to increase the herd. The upper limit of the number of cows in the herd supported by the subsidies should be shifted to the level of 40 cows (Parzonko 2017).

\section{Conclusions}

Poland has relatively good natural conditions for cattle breeding and production of milk (the production potential is higher than the one actually realised in 2015). However, dairy farms in Poland in comparison to other European countries are characterised by small production scale. It leads to low profitability, which impedes taking decisions concerning the development of such labour-intensive and capitalintensive production as dairy cows breeding. na system dopłat bezpośrednich. Przyjęty w Polsce do roku $2014 \mathrm{w}$ sposób szczególny nie promował wsparcia produkcji mleka. Od 2015 roku sytuacja nieco się zmieniała - Sejm Rzeczpospolitej Polskiej przyjął Ustawę „O płatnościach w ramach systemów wsparcia bezpośredniego" wprowadzając: jednolitą płatność obszarową, płatność za zazielenienie, płatność dla młodych rolników, płatność dodatkową i płatności produkcyjne (płatności związane do powierzchni niektórych upraw oraz do liczby posiadanych niektórych gatunków zwierząt) (Dz.U. 2015 poz. 308). W Art. 16.1. ww. ustawy wprowadzono po raz pierwszy „płatności związane do zwierząt” i przysługują one do następujących gatunków: bydło domowe, owca domowa i koza domowa. Płatności te mają charakter produkcyjnych - im większa liczba zwierząt tym przysługujące dopłaty są większe. Jednak wprowadzono pewne ograniczenia dotyczące liczby zwierząt objętych płatnościami. W przypadku krów przyjęto wymóg posiadania minimum 3 sztuk, natomiast maksymalna liczba objęta dopłatami wynosiła 30 sztuk. W przypadku pozostałych grup zwierząt należących do gatunku jakim jest bydło (cielęta, jałówki, itp.) wprowadzono takie same granice (3-30 sztuk). Zmiana ustawy o płatnościach wsparcia bezpośredniego z dnia 21 października 2016 r. (ogłoszona 15.12.2016 r) wprowadziła zmiany, m.in. dotyczące górnej granicy liczby krów i pozostałych zwierząt z gatunku bydła wspieranych dopłatami - zaproponowano 20 sztuk (Dz.U. 2016 poz. 2037). W 2015 roku na płatności bezpośrednie do krów przeznaczono 644888527 zł, natomiast do pozostałych zwierząt z tego gatunku 720233480 zł. Stanowiło to odpowiednio 314,20 i 258,97 zł do jednej sztuki. Trzeba podkreślić, że sama idea wspierania gospodarstw utrzymujących krowy jest dobrą, ale przyjęte granice liczy zwierząt są niezrozumiałe. Powinno nastąpić przesunięcie granic z poziomu 3-20 sztuk krów objętych dopłatami na wyższy poziom - nie ma uzasadnienia ekonomicznego (w kontekście rozwoju tego kierunku produkcji) wpierania gospodarstw utrzymujących 3 krowy. Minimalna wielkość stada, która może skłaniać rolnika do rozważania rozwoju tej działalności (zwiększenia sakli produkcji) w Polsce w 2016 roku kształtowała się na poziomie 10 sztuk. Wsparcie dopłatami tego stada może przechylić szalę w kierunku jego zwiększania. Górna granica stad wpieranych dopłatami do krów powinna być przesunięta na poziom 40 sztuk (Parzonko 2017).

\section{Podsumowanie i wnioski}

Polska charakteryzuje się stosunkowo dobrymi warunkami przyrodniczymi do chowu bydła i produkcji mleka (potencjał produkcyjny jest dużo większy od faktycznie realizowanego w 2015 roku). Jednak gospodarstwa zajmujące się produkcją mleka w Polsce wyróżniają się na tle innych krajów europejskich przeciętnie niewielką skalą produkcji, co przekłada się na małą dochodowość, która utrudniała podejmowanie decyzji o rozwoju pracochłonnej 
In Poland, in 2002-2010 there was a distinct regional differentiation in the pace of the ongoing changes in the dairy sector. The regions, where we observe the development of milk production, include almost the entire Podlaskie Province (without the Hajnów and Sokólski counties), the northern part of the Mazowieckie Province (poviats in the following order: Ostrowski Mazowiecki, Przasnyski, Mławski, Żuromiński, Makowski, Sokołowski, Sierpecki, Węgrowski, Pułtuski) and the south-eastern part of Warmińsko-Mazurskie Province (poviats in the following order: Szczycieński, Piski, Mrągowski, and Ełcki). The region where milk production is limited includes almost entire Podkarpackie Province and the north-western part of the Małopolskie Province.

In the region where milk production was developed, among the main factors determining this situation were the following: historical conditions, no alternative to other activities (poor soil quality, relatively large share of grassland in the structure of farmlands), positive actions taken by management of dairies and implementing training programs. Access to EU structural funds accelerated the process of development of commercial farms after 2004. The main barriers to the further development of milk production in the region defined as "the region where milk production was developed" include: "no land" (very small supply of land, high transaction prices) and dense development of the villages hindering the construction of cow sheds.

Under the RDP 2007-2013, significant funds were allocated to support the modernization of farms. Mainly under measure 121. "Modernization of agricultural holdings" the investments related to the purchase of mobile equipment were made, which accounted for $89 \%$ of all investments. This was partly due to the actual demand and administrative procedures that stimulated these types of investments.

In 2015, the so-called "payments related to animals" were introduced (including cows and other bovine animals), they refer to production. The idea of supporting farms with cows is good, but the designated limitations on the number of livestock are incomprehensible. There should be a shift in the number of subsidised breeding of 3-20 cows to the higher number - there is no economic justification (in the context of the development of this type of production) for supporting farms keeping 3 cows. i kapitałochłonnej produkcji, jaką jest chów krów mlecznych.

W Polsce występowało w latach 2002 - 2010 wyraźne zróżnicowanie regionalne $\mathrm{w}$ tempie dokonujących się zmian w sektorze mleczarskim. Do regionu rozwijającego produkcję mleka można zaliczyć prawie całe województwo podlaskie (bez powiatów hajnowskiego i sokólskiego), północną część województwa mazowieckiego (powiaty w kolejności: ostrowski mazowiecki, przasnyski, mławski, żuromiński, makowski, sokołowski, sierpecki, węgrowski, pułtuski) oraz południowo-wschodnią część województwa warmińsko-mazurskiego (powiaty w kolejności: szczycieński, piski, mrągowski, ełcki). Do regionu ograniczającego produkcję mleka można zaliczyć prawie całe województwo podkarpackie oraz północno - zachodnią część województwa małopolskiego.

W regionie rozwijającym produkcję mleka, wśród głównych czynników wpływających na tę sytuację były: uwarunkowania historyczne, brak alternatywy dla innych działalności (słaba jakość gleb, względnie duży udział użytków zielonych w strukturze użytków rolnych), pozytywne sygnały płynące z mleczarni i realizowane programy szkoleniowe. Możliwości korzystania z funduszy strukturalnych UE przyspieszyły proces rozwoju gospodarstw towarowych po 2004 roku. Do głównych barier dalszego rozwoju produkcji mleka $\mathrm{w}$ regionie zdefiniowanym jako „rozwijający produkcję mleka” zaliczyć można: „brak ziemi” (bardzo mała podaż ziemi, wysokie ceny transakcyjne) oraz zwarta zabudowa wsi utrudniająca budowę obór dla krów.

W ramach PROW 2007-2013 przeznaczono znaczne środki na dofinansowanie modernizacji gospodarstw rolniczych. Głownie w ramach działania 121. „Modernizacja gospodarstw rolnych" realizowano inwestycje związane z zakupem sprzętu ruchomego, które stanowiły 89\% wszystkich inwestycji. Wynikało to po części z faktycznego zapotrzebowania oraz procedur administracyjnych, które stymulowały tego typu inwestycje.

W 2015 roku w polskim systemie dopłat bezpośrednich wprowadzono tzw. „płatności związane do zwierząt" (w tym do krów i pozostałego bydła), mające charakter produkcyjny. Sama idea wspierania gospodarstw utrzymujących krowy jest dobrą, ale przyjęte granice liczy zwierząt są niezrozumiałe. Powinno nastapić przesunięcie granic z poziomu 3-20 sztuk krów objętych dopłatami na wyższy poziom nie ma uzasadnienia ekonomicznego (w kontekście rozwoju tego kierunku produkcji) wpierania gospodarstw utrzymujących 3 krowy.

\section{References/Literatura:}

1. Bański J. (2007), Geografia rolnictwa Polski. Polskie Wydawnictwo Ekonomiczne, Warszawa.

2. Domański R. (2002), Gospodarka przestrzenna. Wydawnictwo Naukowe PWN, Warszawa.

3. Dzun P. (2012), Zmiany strukturalne w chowie krów i produkcji mleka w Polsce w latach 1990-2010. Wieś i Rolnictwo, nr 3 , s. $97-114$.

4. Dzun W. (2003), Nakłady inwestycyjne i bieżace w rolnictwie polskim w świetle dochodów rolników w latach 1990-2001. Wieś i Rolnictwo, nr 3(120), s. 52-71.

5. Falkowski J. (2001), Geografia rolnictwa świata. Wydawnictwo Naukowe PWN, Warszawa. 
6. Hornowski A. (2015), Ocena ekonomicznej efektywności inwestycji finansowanych z działania „Modernizacja gospodarstw rolnych" w ramach PROW 2007-2013 w polskich gospodarstwach rolniczych. Stowarzyszenie Ekonomistów Rolnictwa i Agrobiznesu, Roczniki Naukowe, tom XVII, zeszyt 3, s. 136.

7. Kondracki J. (2000), Geografia regionalna Polski. Wydawnictwo Naukowe PWN, Warszawa.

8. Kuciński K. (2009), Geografia ekonomiczna. Wydawnictwo Wolters Kluwer Polska, Warszawa.

9. Manteuffel R. (1979), Ekonomika i organizacja gospodarstwa rolniczego. PWRiL Warszawa.

10. Michna W. (2001), Polityka rozwoju rolnictwa i obszarów wiejskich oraz jej regionalizacja. Wydawnictwo IERiGŻ, Warszawa.

11. Parzonko A. (2002), Wyniki ekonomiczne gospodarstw wyspecjalizowanych w produkcji mleka zróżnicowanych organizacja powierzchni paszowej. Zeszyty naukowe SGGW, Warszawa, s. 137-149.

12. Parzonko A. (2013), Globalne i lokalne uwarunkowania rozwoju produkcji mleka. Wydawnictwo SGGW, Warszawa.

13. Parzonko A. (2017), Rola dopłat do krów i pozostałego bydła w polskim systemie dopłat bezpośrednich w rozwoju sektora mleczarskiego. Roczniki SERiA T. 19, z. 1, s. 144-150. https://doi.org/10.5604/01.3001.0009.8356

14. Rocznik statystyczny Rolnictwa (2016). Wydawnictwo GUS.

15. Seremak-Bulge J. (red.) (2000-2016), Analizy Rynkowe - Rynek mleka. Wydawnictwo Instytutu Ekonomiki Rolnictwa i Gospodarki Żywnościowej, Warszawa

16. Seremak-Bulge J. (2005), Rozwój rynku mleczarskiego i zmiany jego funkcjonowania w latach 1990-2005, Program Wieloletni 21/2005. IERiGŻ, Warszawa.

17. Sprawozdanie z realizacji Programu Rozwoju Obszarów Wiejskich na lata 2007-2013 za 2014 r. (2014), Ministerstwo Rolnictwa i Rozwoju Wsi, sprawozdanie nr 8, Warszawa.

18. Stola W., Szczęsny R. (2004), Struktura przestrzenna rolnictwa i leśnictwa, W: I. Filera (red.), Geografia gospodarcza Polski. Polskie Wydawnictwo Ekonomiczne, Warszawa, s. 56-76.

19. Ustawa z dnia 21 października 2016 r. o zmianie ustawy o płatnościach w ramach systemów wsparcia bezpośredniego. Dz.U. 2016 poz. 2037.

20. Ustawa z dnia 5 lutego 2015 r. o płatnościach w ramach systemów wsparcia bezpośredniego. Dz.U. 2015 poz. 308.

21. Witkowski M. (1997), Efektywność ekonomiczno-organizacyjna I etapu Projektu Rozwoju Prywatnych Gospodarstw Mlecznych w Turośli, W: F. Maniecki (red.), Postęp techniczny a organizacja gospodarstw rolniczych. Wydawnictwo SGGW, Warszawa, s. 156-163.

22. Ziętara W. (2012), Organizacja i ekonomika produkcji mleka w Polsce, dotychczasowe tendencje i kierunki zmian. Roczniki Nauk Rolniczych, Seria G 99, s. 43-55.

23. Zwolak J. (2007), Ocena reprodukcji środków trwałych w rolnictwie polskim po 1990 roku. Zagadnienia Ekonomiki Rolnej, nr 1, s. 96-104. 